Evidence-Based Case Report

\title{
Prognostic of Recurrence of Ankle Sprain Injury in Athletes who Return to Sports Early
}

\author{
Chikih Chikih, ${ }^{1 *}$ Nani C. Sudarsono, ${ }^{1,2,3}$ Elina Widiastuti, ${ }^{1}$ Anggia Prathama ${ }^{3}$
}

\author{
1Sports Medicine Study Program, Faculty of Medicine Universitas Indonesia \\ ${ }^{2}$ Sports Medicine Division, Department of Community Medicine, Faculty of Medicine Universitas Indonesia \\ ${ }^{3}$ Center for Sports and Exercise Studies Indonesian Medical Education and Research Institute \\ Faculty of Medicine Universitas Indonesia
}

\author{
*Corresponding author: chikih.md.dma@gmail.com \\ Received 4 February 2021; Accepted 17 August 2021 \\ http//doi.org/10.23886/ejki.9.11.137
}

\begin{abstract}
Ankle sprains can occur in all athletes. The injuries are often considered minor but can occur repeatedly which can cause chronic complications. This evidence-based case report aims to determine the prognosis of recurrent ankle sprains resulting from returning to exercise too early. This report uses two databases for evidence collection, namely PubMed and Cochrane. Of the four articles, it was found that recurrent ankle sprains incidence rate was $33 \%$, and neuromuscular training significantly reduced ankle sprain recurrence rates with relative risk 0.63 (95\% Cl: 0.34-0.99) and hazard ratio 0.18 (95\% Cl: 0.07-0.43). The healing time to the pre-injury state reached $93.8 \pm 1.2$ days for conventional therapy and $97.6 \pm 1.5$ days for a surgical procedure, and the time to return to exercise was 46.6 (95\% Cl:15.4-70) days for conventional treatment and $55.2 \pm 15.8$ (95\% Cl: $41.7 \pm 9.8$ ) days for surgical procedure. Using an ankle brace can help in healing and preventing recurrent injuries. Future more, proper handling and education about injuries and when is the optimal time to return to exercise can prevent relapse.
\end{abstract}

Keywords: ankle sprain, return to sports, recurrence injury.

\section{Prognosis Kekambuhan Cedera Sprain Pergelangan Kaki Olahragawan Setelah Kembali Berolahraga Lebih Awal}

\begin{abstract}
Abstrak
Cedera sprain pergelangan kaki dapat terjadi pada semua atlet. Cedera tersebut sering dianggap ringan namun jika terjadi berulang dapat menyebabkan komplikasi kronik. Laporan kasus berbasis bukti ini bertujuan untuk mengetahui prognosis kejadian berulang cedera sprain pergelangan kaki akibat kembali berolahraga terlalu awal. Dua basis data digunakan dalam pengumpulan bukti, yakni PubMed dan Cochrane. Dari empat artikel didapati cedera sprain pergelangan kaki dapat terjadi berulang dengan incidence rate $33 \%$ dan menyatakan neuromuscular training secara signifikan mengurangi tingkat kekambuhan sprain pergelangan kaki dengan relative risk 0.63 (95\% Cl: 0.34-0.99) dan hazard ratio 0.18 (95\% Cl: 0.07-0.43). Waktu

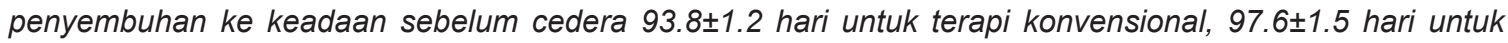
tindakan operatif, waktu kembali berolahraga adalah 46.6 (95\% Cl:15.4-70) hari untuk tindakan konvensional dan $55.2 \pm 15.8$ (95\% Cl: $41.7 \pm 9.8$ ) hari untuk tindakan operasi. Penggunaan penyangga pergelangan kaki dapat membantu proses penyembuhan dan pencegahan cedera berulang. Oleh karena itu penanganan dan edukasi yang tepat mengenai cedera dan menetapkan waktu yang tepat untuk kembali berolahraga dapat mencegah kekambuhan.

Kata kunci: cedera pergelangan kaki, kembali berolahraga, cedera berulang.
\end{abstract}




\section{Introduction}

Ankle sprain injury is a common injury bringing patients into the emergency room or sports medicine clinic. In athletics, the incidence of ankle injuries is $20 \%-40 \%$. Among college-level athletes in the United States, ankle sprains are the most commonly reported injury, accounting for $15 \%$ of all reported injuries. ${ }^{1}$

The majority of ankle injuries are sportsrelated and involve injury to the ankle compartment during running, jumping, and quick changes of direction. ${ }^{2,3}$ The anatomical compartment of the ankle consists of the anterior talofibular ligament (ATFL), calcaneofibular ligament (CFL), posterior talofibular ligament (PTFL), anterior inferior tibiofibular ligament (AITFL), posterior inferior tibial ligament (PITL), and the Achilles tendon.4 Based on the ankle's anatomical position and mechanism of the injury, ankle sprain injury is divided into two primary categories: high ankle injury/syndesmosis ankle injury and lateral ankle injury. High ankle injury occurs when the AIFTL and PITL are involved in an external rotation mechanism of injury. Lateral ankle injury occurs when the ATFL, PTFL, and CFL, either individually or in combination, are implicated in an internal rotation mechanism of injury. ${ }^{3,5}$

Ankle sprain injury treatment is tailored to the patient's clinical condition. The diagnosis is usually made based on a history of the injury; in certain cases, magnetic resonance imaging (MRI) examination is required to confirm the type of ankle sprain. Clinically, ankle sprain injuries are divided into three grades: grade I (mild), grade II (moderate), and grade III (severe). Grade I and II sprains usually recover with conservative management. However, with grade III sprains, the optimal management approach is still debated; some prefer surgery and others favor conservative treatment. ${ }^{6,7}$

Conservative treatment aims to rehabilitate the injured ligaments in the ankle; treatment usually lasts 2-4 weeks after acute injury, followed by 2-3 months of strengthening exercises for the peroneal muscles.3,8 Treatment begins with rest, ice, compression, elevation (RICE), non-steroidal anti-inflammatory drugs, use of a functional brace (tubular bandage or air cast brace), and sometimes neuromuscular electrical stimulation by a trained physical therapist. $3,8,9$

Evaluation of the functional capacity of the ankle joint is urgently needed. The mean time required for ankle healing ranges from 7 days to 9 months. 8 This long period of therapy and recovery can cause athletes to become impatient to return to training or participate in competitions. This article aims to improve the understanding of the risk of recurring ankle sprain injuries due to early return to sports.

\section{Case Illustration}

A 39-year-old male athlete experienced pain in his left ankle while participating in a running competition and was diagnosed with an acute ankle injury. The patient was prescribed an 8-week physical therapy program, though he returned to running activities before the completion of the program. While running, he felt pain again in his left ankle. At this point, he was 3 weeks into his physical therapy program, and he was not wearing an ankle brace while running. Due to the discomfort in his ankle, he took pain medications.

\section{Clinical Question}

What is the likelihood of ankle sprain injury reoccurrence on the same side due to early return to sport?

\section{Methods \\ Search Strategy and Eligibility}

As the clinical question is prognostic, it can be answered with systematic reviews of prognosis studies, cohort studies, randomized controlled trials (RCTs), case-control studies, and case series studies. Literature searches of peer-reviewed digital articles were performed in PubMed and Cochrane using single or combinations of keywords using Boolean AND/OR, including calcaneofibular ligament injury, recurrent sprain, return to sports, and ankle sprain.

The inclusion criteria for articles consisted of (1) article titles and abstracts containing calcaneofibular ligament or ankle sprain injuries that were published between 2010 and 2020, (2) article titles and abstracts containing recurrence and return to sport after experiencing a sprain injury published between 2010 and 2020, (3) articles that could be accessed in English, and (4) all levels of evidence. Exclusion criteria consisted of (1) seminar articles, (2) articles with a narrative study or case report design, (3) consensus articles, and (4) studies on animals.

\section{Screening}

The screening was conducted using the Preferred Reporting Items for Systematic Reviews and Meta-Analyses (PRISMA) guidelines. ${ }^{10}$ Three independent reviewers performed the screening of 
duplicates, titles and abstracts, and full-text articles. The reviewers studied the articles according to the inclusion criteria and if there were inconsistencies between reviewers during the title and abstract selection stages, the articles were automatically entered into the full-text selection stage. Differences were resolved through discussion and agreement between the three reviewers. If an agreement was not reached, the supervisor, who acted as the fourth reviewer, assisted in the decision-making process.

\section{Data Extraction}

Three reviewers extracted data from selected and included studies. Data recorded consisted of the author, year of publication, study design, study characteristics (number of subjects, age of subjects, percentage of subjects), study intervention, outcomes (recurrence event, time to return to exercise), and relevant findings that could answer the clinical question.

\section{Results}

The article search was carried out on September 23, 2020. There were 658 articles screened from PubMed and 36 from Cochrane, and a check for duplicates was performed for articles from both PubMed and Cochrane. The search mechanism is described in Figure 1. After the application of inclusion and exclusion criteria, four articles were found to be relevant to answering the clinical question. The four articles consisted of three systematic reviews and one case series. Data extraction of the study characteristics was carried out for the four articles and is presented in Table 1. The prognostic case series was critically reviewed based on the rapid critical appraisal of prognostic study from the Center of Evidence-Based Medicine (CEBM), University of Oxford, as described in Table 2. The selected systematic reviews were critically reviewed based on standard evaluations for systematic review from CEBM, University of Oxford, as described in Table 3.

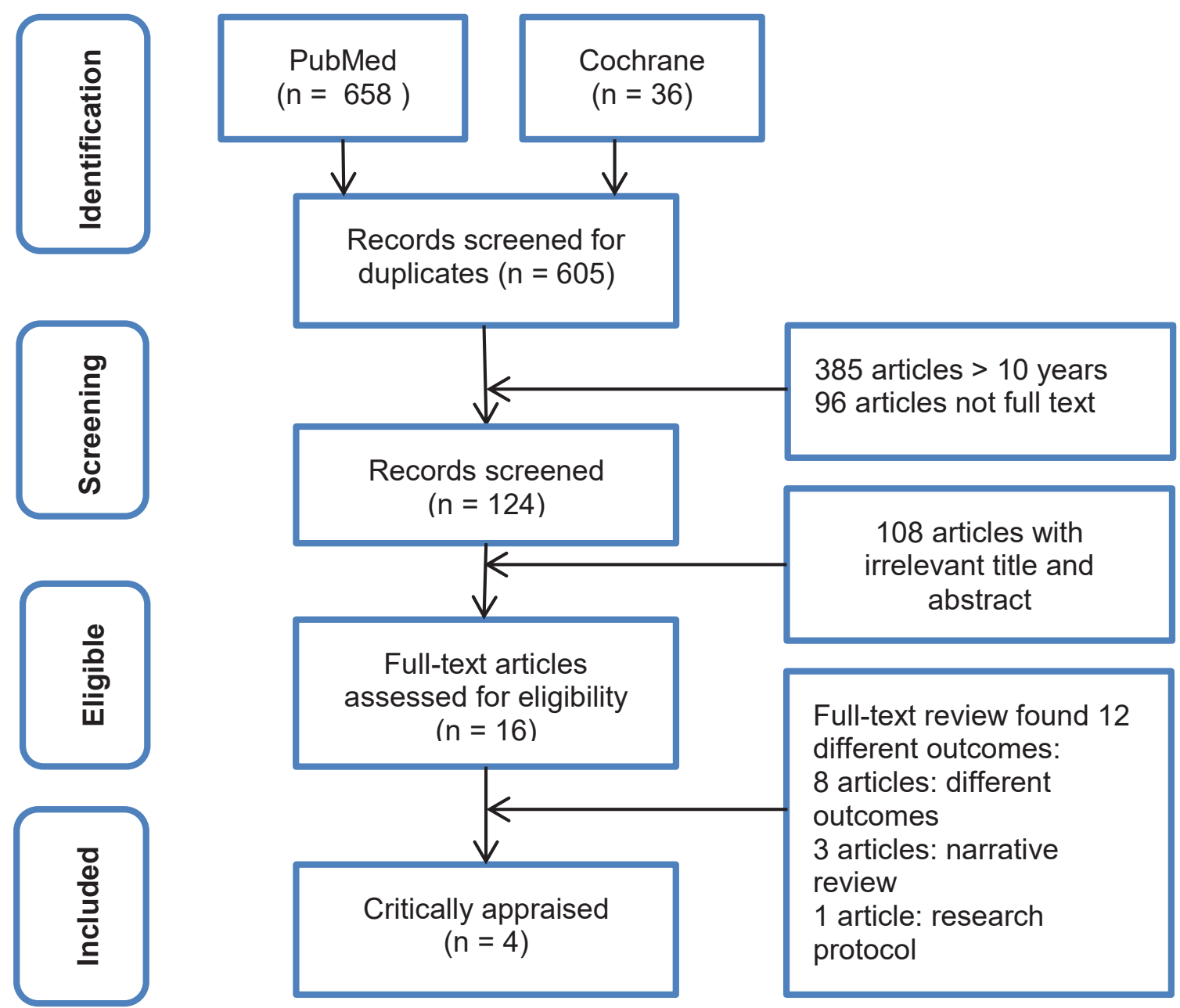

Figure 1. Flowchart Describing Systematic Search and Results from Two Databases. 


\section{Discussion}

The three systematic review articles did not perform meta-analyses and did not include forest plots. Nevertheless, these three articles were equipped with tables detailing the characteristics of the selected studies, which contained studies suitable for answering the clinical question in this evidence-based case report. According to Mackenzie et al, ${ }^{1}$ ankle sprain injury is an injury characterized by stretching or tearing the ligaments of the ankle. Based on the anatomical position, the incidence rate of high ankle injuries is 0.060.38 per 1,000 AE (Athlete exposure) and the incidence rate of lateral ankle injuries is $0.93 \mathrm{per}$ $1,000 \mathrm{AE}$ (Athlete exposure). ${ }^{1}$ A review by Fong et al5 explained that the risk factors for ankle sprain injury were related to either extrinsic or intrinsic factors. Extrinsic factors include athletic footwear, exercise intensity, running route, and running schedule. Intrinsic factors reside within the athlete and include history of previous ankle sprain injury, foot size, changes in foot posture from eversion to inversion, plantar strength/flexibility, the ratio between dorsiflexion and plantar-flexion, and foot dominance. All extrinsic and intrinsic factors can be predisposing factors increasing the occurrence of the ankle sprain injury. ${ }^{5}$

Ligament injuries to the ankle often lead to ankle instability. Previous studies reported that $74 \%$ of patients suffer from ankle sprains because of biomechanical trauma. Internal or external rotation forces to the ankle can cause symptoms persisting for $4-5$ years, and $10 \%-30 \%$ of patients with chronic symptoms develop complications in the form of persistent synovitis or tendinitis, ankle stiffness, pain, and muscle weakness. 5 In the review article by Mackenzie et al, ${ }^{1}$ one of the risk factors for recurrent ankle sprain injury was a previous history of an ankle sprain.

People with a history of injury have a 3.5 times higher risk of recurrent injury than people with first-time injuries. Therapeutic interventions for ankle sprain and prevention of repetitive injury have focused on musculoskeletal strengthening, consisting of balance exercises, proprioception, and biomechanical enhancement, which has shown benefits for preventing lower limb musculoskeletal injury, reducing pain, and correcting muscle dysfunction. $^{1}$

Petersen et al $^{11}$ discussed the significance of recurrent ankle sprain injuries due to a history of previous ankle sprain and reported a $33 \%$ incidence of ankle sprain injury recurrence, though did not consider other prognostic factors such as age, sex, and the cause of the recurrence..$^{1,11}$

Neuromuscular training significantly reduced ankle sprain recurrence rate by 0.63 (95\% Cl: 0.34 0.99) compared to the non-adherent group, with a hazard ratio of $0.18(95 \% \mathrm{Cl}: 0.07-0.43)$ compared to the conventional therapy group. ${ }^{11}$ Verhagen et $\mathrm{al}^{12}$ concluded that balance training and/or neuromuscular training programs can be used to reduce the risk of recurrent injury in athletes with a history of previous ankle sprain injuries. None of the articles explained the types of sports activities that caused recurrence or whether there was a relationship between returning to sports earlier and injury recurrence. Other factors that contributed to the cause of ankle sprain recurrence were not described in this article. ${ }^{13,14}$

Vancolen et $\mathrm{al}^{15}$ studied high ankle injury (syndesmotic injury) and found that the return rate of the ankle to the pre-injury condition was $93.8 \%$ $\pm 1.2 \%$ for conventional therapy and $97.6 \% \pm 1.5 \%$ for surgery and that the time required to return to sports overall was 46.6 (95\% Cl: 15.4-70) days, with a mean of $55.2 \pm 15.8$ days for operative management and $41.7 \pm 9.8$ days for nonoperative management. There was no explanation regarding other prognostic factors such as age, sex, and type of rehabilitation exercise performed to return to the pre-injury state. There was no definitive explanation regarding the ideal time to return to sports from the perspective of the patient's physical condition and the clinical examination. Operative management was only performed for grade II and III injuries, with trans-syndesmotic and arthroscopic techniques employed.

Nonoperative management was carried out through rest, ice, compression, elevation (RICE) and lower limb muscle balance and coordination exercises. Return to sports was defined differently than the rest of the literature, so it is difficult to ascertain the standard recovery period before return to sports. It is recommended for athletes to return to sports when they have completed all functional rehabilitation training programs. The article by Vancolen et $\mathrm{al}^{15}$ strengthens the statement by Gwendolyn et $\mathrm{al}^{16}$ that, in theory, $30 \%-40 \%$ of lateral sprain injuries can develop into chronic ankle instability. One important note is that if the patient has a repeated sprain injury and symptoms persist or recur within 12 months, this is an indication for operative management. ${ }^{15,16}$ 
Table 1. Characteristics of Included Studies

\begin{tabular}{|c|c|c|c|c|}
\hline Study & $\begin{array}{l}\text { Study } \\
\text { Characteristics }\end{array}$ & Intervention & Outcomes & Relevant Findings \\
\hline $\begin{array}{l}\text { Systematic review by } \\
\text { Petersen } \\
\text { et al, }{ }^{11} \\
2013\end{array}$ & $\begin{array}{l}\text { Subjects: athletes } \\
\text { aged } \geq 16 \text { years } \\
3 \text { RCTs and } 1 \text { case- } \\
\text { control article }\end{array}$ & $\begin{array}{l}\text { Subjects were divided } \\
\text { into two groups. The } \\
\text { intervention group received } \\
\text { a neuromuscular training } \\
\text { program. The control group } \\
\text { received RICE. }\end{array}$ & $\begin{array}{l}\text { Follow-up every } \\
3 \text { months for } 1 \\
\text { year. Observed for } \\
\text { recurrence rate. }\end{array}$ & $\begin{array}{l}\text { Recurrence occurred in } 56(22 \%) \\
\text { subjects in the intervention group } \\
\text { and } 89(33 \%) \text { in the control group. } \\
\text { Neuromuscular training significantly } \\
\text { reduced the recurrence rate of ankle } \\
\text { sprain (RR } 0.63 \mathrm{Cl} \text { [0.43-0.99]; HR } \\
0.18 \mathrm{Cl}[0.07-0.43]) \text {. }\end{array}$ \\
\hline $\begin{array}{l}\text { Systematic review by } \\
\text { Thompson et al, }{ }^{17} 2017\end{array}$ & $\begin{array}{l}9 \text { studies were } \\
\text { included: } \\
6 \text { prospective } \\
\text { cohort studies and } \\
3 \text { retrospective } \\
\text { cohort studies }\end{array}$ & $\begin{array}{l}\text { Prospective and } \\
\text { comprehensive studies } \\
\text { investigating the } \\
\text { association between } \\
\text { baseline prognostic factors } \\
\text { and recovery over time for } \\
\text { ankle sprain injuries. }\end{array}$ & $\begin{array}{l}\text { Prognostic factors } \\
\text { - Short-term recovery } \\
\text { ( } \leq 8 \text { weeks) } \\
\text { - Medium-term } \\
\text { recovery ( } \leq 4 \\
\text { months) } \\
\text { - Long-term recovery } \\
\text { (>4 months) }\end{array}$ & $\begin{array}{l}\text { The prognostic factors for } \\
\text { unsatisfactory results in the } \\
\text { healing of lateral ankle sprains } \\
\text { were grouped into } 8 \text { weeks, } 4 \\
\text { months, and > } 4 \text { months of follow- } \\
\text { up. }\end{array}$ \\
\hline $\begin{array}{l}\text { Systematic review by } \\
\text { Vancolen } \\
\text { et al, }{ }^{15} 2019\end{array}$ & $\begin{array}{l}10 \text { studies on high } \\
\text { ankle injury or } \\
\text { syndesmotic injury }\end{array}$ & $\begin{array}{l}\text { A neuromuscular } \\
\text { rehabilitation program was } \\
\text { used for the operative } \\
\text { and the nonoperative } \\
\text { treatment group. }\end{array}$ & $\begin{array}{l}\text { Return to pre-injury } \\
\text { - Time to return to ex- } \\
\text { ercise with operative } \\
\text { management } \\
\text { - Time to return to ex- } \\
\text { ercise with nonopera- } \\
\text { tive management }\end{array}$ & $\begin{array}{l}\text { Rate of return to pre-injury after an } \\
\text { ankle injury was } 93.8 \% \pm 1.2 \% \text { and } \\
97.6 \% \pm 1.5 \% \text {, respectively. The } \\
\text { mean time to return to exercise } \\
\text { was } 46.4 \mathrm{Cl}(15.4-70) \text { days, with } \\
55.2 \pm 15.8 \text { days for operative and } \\
41.7 \pm 9.8 \text { days for nonoperative } \\
\text { management. }\end{array}$ \\
\hline $\begin{array}{l}\text { Prospective case series by } \\
\text { Wells } \\
\text { et al, }{ }^{18} 2019\end{array}$ & $\begin{array}{l}10 \text { subjects with } 7 \\
\text { females and } 3 \text { males, } \\
\text { mean age } 26.7 \text {, range } \\
16-51 \text { years old }\end{array}$ & $\begin{array}{l}\text { RICE, brace, initial home } \\
\text { exercises, ankle brace } \\
\text { use for } 6-12 \text { weeks in } \\
\text { the acute phase and } \\
\text { continued for } 1 \text { year. }\end{array}$ & $\begin{array}{l}\text { Recurrent ankle } \\
\text { sprain rate at } 6 \text { and } 12 \\
\text { months, ankle ROM } \\
\text { evaluation at } 12 \text { weeks }\end{array}$ & $\begin{array}{l}\text { At 1-year follow-up, } 1 \text { subject } \\
\text { reported recurrent ankle sprain injury. } \\
\text { At } 6 \text {-month follow-up, } 2 \text { subjects } \\
\text { reported recurrent ankle sprain } \\
\text { while sprinting. }\end{array}$ \\
\hline
\end{tabular}

Table 2. Rapid Critical Appraisal of Prognostic Study

\begin{tabular}{lc}
\hline \multicolumn{1}{c}{ Question } & Wells et al ${ }^{18}$ \\
\hline Patients assembled at a common (usually early) point in the course of their disease? & Yes \\
Patient's follow-up sufficiently long and complete? & No \\
Were outcome criteria either objective or applied in a 'blind' fashion? & A recurrent presentation \\
Outcomes over time? & Unclear, Cl 95\% \\
How precise is the prognostic estimate? & Yes, as initial input for my patient \\
\hline
\end{tabular}

The study by Thompson et al $^{17}$ described various prognostic factors related to the causes of unsatisfactory results in the healing process of an ankle sprain injury. The prognostic factors were divided by short- ( $<8$ weeks), medium- ( $\leq 4$ months), and long-term (> 4 months) follow-up. At short-term follow-up, several prognostic factors were found, such as age, swelling, reduced range of motion, pain intensity, self-reported physical limitations, self-reported athletic ability, injury severity, ankle function score, and weight-bearing ability/status. At medium-term follow-up, the prognostic factors were age, non-inversion injury, pain (medial joint line) at week 4, pain (in weight-bearing joints) at week 4, and weight-bearing status. Meanwhile, at long-term follow-up, the prognostic factors were age, female gender, MRI findings (degree of severity, number of ligaments, bruised bones), pain (at rest) for 3 months, and re-sprains within 3 months. Of all the prognostic factors, only age was a consistent prognostic factor in determining the success of the healing process of an ankle sprain. There is a substantial gap in understanding of prognostic factors for poor recovery of an ankle sprain. ${ }^{17}$ 
The case series study reported by Bradley et al. consistently addressed the clinical question, as all patients were enrolled at the initial stage of the ankle sprain and were then prescribed gradual therapy including conventional therapy, neuromuscular exercises, and use of a brace. Follow-up was performed and found one recurrence event after 12 months in which the recurrence occurred as a result of the patient returning to running without using the brace. This study also suggested the benefit of using an ankle brace, which participants wore when exercising and doing routine activities for up to 1 year. The use of an ankle brace prevents the recurrence of ankle injuries when exercising, which is evident from the report of one subject who returned to running without using an ankle brace and suffered repeated injuries to the same ankle.18

The four articles used in the EBCR did not mention whether returning to sports early can lead to the recurrence of ankle sprains. Even so, these EBCR articles are well summarized and can be used to answer the patient's questions regarding ankle sprain injury recurrence and the average time to return to sports. In these EBCR articles, it was also found that surgical treatment for ankle sprain injury was chosen when the ankle sprain recured chronically and that there is a benefit to using an ankle brace as a preventative measure. These possibilities need to be explained to the patient. Regarding the presence or absence of other prognostic factors that can disrupt the healing process, only age was found as a consistent prognostic factor. ${ }^{11,15,17,18}$

Table 3. Rapid Critical Appraisal of Systematic Review

\begin{tabular}{|c|c|c|c|}
\hline Question & Petersen et al ${ }^{11}$ & Thompson et al ${ }^{17}$ & Vacuole et al ${ }^{15}$ \\
\hline $\mathrm{PICO}$ & $\begin{array}{l}\text { Subjects with ankle sprain } \\
\text { injury; neuromuscular training } \\
\text { program; compared to } \\
\text { conventional therapy; outcome } \\
\text { of recurrence rate }\end{array}$ & $\begin{array}{l}\text { Subjects with ankle sprain } \\
\text { injury; prognostic factors for } \\
\text { recovery outcomes }\end{array}$ & $\begin{array}{l}\text { Subjects with high ankle } \\
\text { sprain injury; operative } \\
\text { treatment; compared to } \\
\text { nonoperative; outcome } \\
\text { of reinjury rate and time } \\
\text { to return to sports }\end{array}$ \\
\hline $\begin{array}{l}\text { Does the systematic review } \\
\text { address a focused question } \\
\text { (PICO)? }\end{array}$ & Yes & Yes & Yes \\
\hline $\begin{array}{l}\text { Does PICO use it to direct the } \\
\text { search and select articles for } \\
\text { inclusion? }\end{array}$ & Yes & Yes & Yes \\
\hline $\begin{array}{l}\text { F: Did the search find all the } \\
\text { relevant evidence? }\end{array}$ & Yes & Yes & Yes \\
\hline $\begin{array}{l}\text { A: Have the studies been } \\
\text { critically appraised? }\end{array}$ & $\begin{array}{l}\text { Unclear; the article selection is } \\
\text { described but not how articles } \\
\text { were reviewed }\end{array}$ & Yes & Yes \\
\hline $\begin{array}{l}\text { I: Did they only include high- } \\
\text { quality studies? }\end{array}$ & Unclear & Unclear & Yes \\
\hline $\begin{array}{l}\text { T: Have the results been totaled } \\
\text { up with appropriate summary } \\
\text { tables and plots? }\end{array}$ & No & No & No \\
\hline $\mathrm{H}:$... and heterogeneity between & No & No & No \\
\hline
\end{tabular}

What measure is used, how big is the effect (could it be by chance)?

Result and the result presented
Recurrence rate

Relative risk

Hazard ratio

We can provide an explanation to the patient about the possibility of ankle sprain recurrence.

However, whether early return to sport causes recurrence still needs to be studied.
The prognostic factors for short-, medium-, and longterm recovery

We can provide an overview of prognostic factors that may cause a mismatch in the healing process of the ankle injury. Early return to sports causing recurrence needs to be studied further.
Return to pre-injury rate Average number of days of treatment

We can explain the average time to return to exercise in athletes to patients, as well as the possibility of surgery. 


\section{Conclusion}

Ankle sprain injuries can occur repeatedly and many factors can affect them. The time to return to sports is an important factor, as athletes may participate in their sport even when the injury has not healed optimally. The ideal time to return to sports was not explained in detail in these studies, but all agreed to adjust it to the athlete's level of recovery as seen from the results of physical examination and subjective complaints. Management of ankle sprains can range from conventional therapy to surgical management, depending on the degree of injury. Using an ankle brace can aid in the healing process and prevent recurrences, especially in a more severe injury. Additionally, a neuromuscular training program can prevent the recurrence of ankle sprain injuries. There is a lack of clarity regarding underlying prognostic factors affecting recovery after an ankle sprain.

\section{References}

1. Herzog MM, Kerr ZY, Marshall SW, Wikstrom EA. Epidemiology of Ankle Sprains and Chronic Ankle Instability. J Athl Train [Internet]. 2019 Jun 1;54(6):603-10. https://doi.org/10.4085/1062-6050447-17

2. Doherty C, Bleakley C, Delahunt E, Holden S. Treatment and prevention of acute and recurrent ankle sprain: an overview of systematic reviews with meta-analysis. $\mathrm{Br} \mathrm{J}$ Sports Med [Internet]. 2017 Jan;51(2):113-25. https://doi.org/10.1136/ bjsports-2016-096178

3. Al-Mohrej OA, Al-Kenani NS. Acute ankle sprain: Conservative or surgical approach? EFORT Open Rev [Internet]. 2016;1(2):34-44. https://doi. org/10.1302/2058-5241.1.000010

4. Dubin JC, Comeau D, McClelland RI, Dubin RA, Ferrel E. Lateral and syndesmotic ankle sprain injuries: A narrative literature review. J Chiropr Med [Internet]. 2011;10(3):204-19. http://dx.doi. org/10.1016/j.jcm.2011.02.001

5. Fong DT, Chan Y-Y, Mok K-M, Yung PS, Chan K-M. Understanding acute ankle ligamentous sprain injury in sports. BMC Sports Sci Med Rehabil [Internet]. 2009 Dec 30;1(1):14. https://doi.org/10.1186/17582555-1-14

6. Tiemstra JD. Update on acute ankle sprains. Am Fam Physician [Internet]. 2012;85(12):1170-6. Available from: https://www.aafp.org/afp/2012/0615/ afp20120615p1170.pdf

7. Alferraly TI. Anterior Talofibular Ligament (ATFL) Reconstruction With Modified Brostrom-Gould Technique Using Fiber Wire: Laporan Kasus. 2008;41(2):144-50. Available from: https://www.ejournal.unair.ac.id/JOINTS/article/view/16587/8952
8. Ortega-Avila AB, Cervera-Garvi P, MarchenaRodriguez A, Chicharro-Luna E, Nester CJ, Starbuck C, et al. Conservative Treatment for Acute Ankle Sprain: A Systematic Review. J Clin Med [Internet]. 2020;9(10):3128. https://doi.org/10.3390/ jcm9103128

9. van den Bekerom MPJ, Sjer A, Somford MP, Bulstra $\mathrm{GH}$, Struijs PAA, Kerkhoffs GMMJ. Non-steroidal anti-inflammatory drugs (NSAIDs) for treating acute ankle sprains in adults: benefits outweigh adverse events. Knee Surgery, Sport Traumatol Arthrosc [Internet]. 2015;23(8):2390-9. https://doi. org/10.1007/s00167-014-2851-6

10. Liberati A, Altman DG, Tetzlaff J, Mulrow C, Gøtzsche PC, loannidis JPA, et al. The PRISMA Statement for Reporting Systematic Reviews and Meta-Analyses of Studies That Evaluate Health Care Interventions: Explanation and Elaboration. PLoS Med [Internet]. 2009 Jul 21;6(7):e1000100. https://doi.org/10.1136/ bmj.b2700

11. Petersen W, Rembitzki IV, Koppenburg AG, Ellermann A, Liebau C, Brüggemann GP, et al. Treatment of acute ankle ligament injuries: $A$ systematic review. Arch Orthop Trauma Surg [Internet]. 2013;133(8):1129-41. https://doi. org/10.1007/s00402-013-1742-5

12. Vuurberg G, Hoorntje A, Wink LM, Van Der Doelen BFW, Van Den Bekerom MP, Dekker R, et al. Diagnosis, treatment and prevention of ankle sprains: Update of an evidence-based clinical guideline. $\mathrm{Br} \mathrm{J}$ Sports Med [Internet]. 2018;52(15):956. https://doi. org/10.1136/bjsports-2017-098106

13. Alahmari KA, Silvian $P$, Ahmad I, Reddy RS, Tedla JS, Kakaraparthi VN, et al. Effectiveness of Low-Frequency Stimulation in Proprioceptive Neuromuscular Facilitation Techniques for Post Ankle Sprain Balance and Proprioception in Adults: A Randomized Controlled Trial. Biomed Res Int [Internet]. 2020;2020:1-13. https://doi. org/10.1155/2020/9012930

14. de-las-Heras Romero J, Alvarez AML, Sanchez FM, Garcia AP, Porcel PAG, Sarabia RV, et al. Management of syndesmotic injuries of the ankle. EFORT Open Rev [Internet]. 2017;2(9):403-9. https://doi.org/10.1302/2058-5241.2.160084

15. Vancolen SY, Nadeem I, Horner NS, Johal $H$, Alolabi B, Khan M. Return to Sport After Ankle Syndesmotic Injury: A Systematic Review. Sports Health [Internet]. 2019;11(2):116-22. https://doi. org/10.1177/1941738118816282

16. Vuurberg G, Wink LM, Blankevoort L, Haverkamp D, Hemke R, Jens S, et al. A risk assessment model for chronic ankle instability: Indications for early surgical treatment? An observational prospective cohort - study protocol. BMC Musculoskelet Disord [Internet]. 2018;19(1):1-11. https://doi.org/10.1186/ s12891-018-2124-5 
17. Thompson JY, Byrne C, Williams MA, Keene DJ, Schlussel MM, Lamb SE. Prognostic factors for recovery following acute lateral ankle ligament sprain: A systematic review. BMC Musculoskelet Disord [Internet]. 2017;18(1):1-14. https://doi. org/10.1186/s12891-017-1777-9
18. Wells B, Allen C, Deyle G, Croy T. MANAGEMENT OF ACUTE GRADE II LATERAL ANKLE SPRAINS WITH AN EMPHASIS ON LIGAMENT PROTECTION: A DESCRIPTIVE CASE SERIES. Int J Sports Phys Ther [Internet]. 2019 Jun;14(3):44558. https://doi.org/10.26603/ijspt20190445 